I Ask for Justice 
Book Thirty-Three

Louann Atkins Temple Women E Culture Series

Books about women and families, and their changing role in society 


\section{Ask for Justice}

Maya Women, Dictators, and Crime in Guatemala, 1898-1944

BY DAVID CAREY JR.

University of Texas Press $\underset{\sim}{ }$ Austin 
The Louann Atkins Temple Women \& Culture Series is supported by Allison, Doug, Taylor, and Andy Bacon; Margaret, Lawrence, Will, John, and Annie Temple; Larry Temple; the Temple-Inland Foundation; and the National Endowment for the Humanities.

This book draws on material previously published as the following:

"Distilling Perceptions of Crime: Maya Moonshiners and the Guatemalan State, 1898-1944" in Distilling the Influence of Alcohol: Aguardiente in Guatemalan History (Gainesville: University Press of Florida, 2012). Reprinted with permission of the University Press of Florida.

"Forced and Forbidden Sex: Rape and Sexual Freedom in Dictatorial Guatemala" in The Americas: A Quarterly Review of Inter-American Cultural History 69, no. 3 (January 2013): 357-389.

“'Hard Working, Orderly Little Women': Mayan Vendors and Marketplace Struggles in Early-Twentieth-Century Guatemala" in Ethnohistory 55, no. 4 (Fall 2008): 579-607. Copyright 2009, American Society for Ethnohistory. All rights reserved. Reprinted by permission of the publisher, Duke University Press.

“'Oficios de su raza y sexo' (Occupations Consistent with Her Race and Sex): Mayan Women and Expanding Gender Identities in Early Twentieth-Century Guatemala" in Journal of Women's History 20, no. 1 (Spring 2008): 114-148.

"Precursors to Femicide: Guatemalan Women in a Vortex of Violence" in Latin American Research Review 45, no. 3 (2010): 142-164.

Copyright (C) 2013 by the University of Texas Press

All rights reserved

Printed in the United States of America

First edition, 2013

Requests for permission to reproduce material from this work should be sent to:

Permissions

University of Texas Press

P.O. Box 7819

Austin, TX 78713-7819

http://utpress.utexas.edu/index.php/rp-form

(2) The paper used in this book meets the minimum requirements of ANSI/NISO Z39.48-1992 (R1997) (Permanence of Paper).

\section{Library of Congress Cataloging-in-Publication Data}

Carey, David, 1967-

I ask for justice : Maya women, dictators, and crime in Guatemala, 1898-1944 / by

David Carey Jr. - First edition.

pages $\quad \mathrm{cm} .-$ (Louann Atkins Temple women \& culture series; Book thirty-three)

Includes bibliographical references and index.

ISBN 978-0-292-74868-2 (cloth : alk. paper)

1. Sex discrimination in criminal justice administration-Guatemala-History20th century. 2. Maya women-Legal status, laws, etc.-Guatemala-History20th century. 3. Maya women-Crimes against-Guatemala-History-20th century. 4. Maya women-Guatemala—Social conditions-20th century.

I. Title. 
For the bright, industrious, and resourceful women and girls closest to my heart: Mom, Sarah, Ava, and Kate

In memory of Mary, Bob, and Jay, who all passed away while I was writing this book 
THIS PAGE INTENTIONALLY LEFT BLANK 